\title{
A Study to Assess the Effectiveness of Structured Teaching Programme on Knowledge and Attitude Regarding Vitamin A Deficiency and Its Prophylaxis among Mothers of Under Five Children at Selected village at Tamilnadu
}

\author{
Roslin Mangaiyarkarasi. M. ${ }^{1}$, Kumudhavalli. $D^{2}$, R. Karthi ${ }^{3}$ \\ ${ }^{1}$ M.Sc (N) E. S. College of Nursing, Villupuram, Tamilnadu \\ ${ }^{2}$ Assistant Professor, E. S. College of Nursing, Villupuram, Tamilnadu \\ ${ }^{3}$ Professor cum Vice Principal, E. S. College of Nursing, Villupuram, Tamilnadu
}

Corresponding Author: Kumudhavalli. D

\begin{abstract}
Aim: to assess the effectiveness of structured teaching programme on knowledge and attitude regarding vitamin A deficiency and its prophylaxis among mothers of under five children.

Objectives: (1). To assess the knowledge and attitude among mothers of under five children on vitamin A deficiency and its Prophylaxis. (2). To find the effectiveness of Structured Teaching Programme in terms of gaining knowledge and attitude of mothers regarding Vitamin A deficiency and its prophylaxis for under five children. (3). To find association between the pre test level of knowledge and attitude among mothers of under five children with their selected demographic variables.
\end{abstract}

Methodology: A pre experimental research design was adopted for the study. 50 samples were selected by using non probability convenience sampling technique. The pre and post test level knowledge and attitude was assessed by using structured knowledge questionnaires and attitude scale respectively.

Results: The pre test mean was 7.76 with the standard deviation of 2.17 and the post test mean was 16.68 with the standard deviation of 1.81. The mean difference of pre and post test is 8.92; standard error is 0.281 . The ' $\mathrm{T}$ ' value is 31.74 is Highly Significant at $p<0.05$. The pre test mean was 8.98 with the standard deviation of 3.47 and the post test mean was 24.56 with the standard deviation of 3.45 . The mean difference of pre and post test is 15.58; standard error is 0.43 . The ' $T$ ' value is 36.23 is Highly Significant $p<0.05$. Hence it indicates the knowledge and attitude level of mothers are improved after structured teaching programme.

Conclusion: The study concluded that structured teaching programme was effective and improved knowledge and attitude regarding vitamin A deficiency and its prophylaxis among mothers of under five children.

Key words: structured teaching programme, Vitamin A, Prophylaxis

\section{INTRODUCTION}

Children are an embodiment of our dreams, hopes for the future. They are wet clay in the potters hands, handled with care they become something beautiful else. They break and become discarded. They are the most vulnerable group in the society.

Nutrition is recognized as an important determinant of health and development of societies. It is estimated that each year $55 \%$ of deaths among children under five can be either directly or indirectly is due to hunger and malnutrition in developing countries including India. Apart from the protein energy malnutrition, inadequate intake of micronutrients such as Vitamin A and Vital Minerals (Iron, 
Roslin Mangaiyarkarasi. M. et.al. A study to assess the effectiveness of structured teaching programme on knowledge and attitude regarding vitamin A deficiency and its prophylaxis among mothers of under five children at selected village at Tamilnadu.

Calcium, Iodine and Zinc) are recognized to affect younger children.

Vitamin-A deficiency is one of the major public health problems among Children. In children, Vitamin-A deficiency disorder is the leading cause of preventable visual impairment and blindness. Vitamin-A was estimated to affect between 75 and 254 million preschool children each year. Vitamin A deficiency is the second most important factor for global blindness. Every year 2,50,000 to 500,000 children become blind partially or totally due to vitamin A deficiency and it lowers the resistance power of these children against infection

WHO/UNICEF has recommended that vitamin A supplementation should be part of routine and supplemental immunization activities in all countries where vitamin A deficiency is, or is likely to be, a public health problem, which includes India as well. It has been recently suggested that there is a unique opportunity to increase high-dose vitamin A supplementation at regular immunization contact and through National Immunization Days (NIDs); many countries have already adopted the latter option.

Even though many National Programmes are being conducted on nutritional deficiencies, the investigator has observed reported cases of blindness due to vitamin A deficiency during her working period. While conducting the survey of administration of vitamin A suspension as every six months for under five children most mothers are not aware and not administered vitamin A suspension after the $2^{\text {nd }}$ dose. Hence it is essential for the parents especially mothers to have adequate knowledge about the vitamin A prophylaxis and supplementation for the proper health of their children. Mothers need more instruction and information regarding vitamin A supplementation. So, the investigator structured teaching program is an important and effective method by which mothers can improve their knowledge. This led to the selection of problem for research study.

\section{STATEMENT OF THE PROBLEM:}

A study to assess the Effectiveness of Structured Teaching Programme on Knowledge and Attitude regarding Vitamin A Deficiency and its prophylaxis among mothers of under five children at selected village at Tamilnadu.

\section{OBJECTIVES}

- To assess the knowledge and attitude among mothers of under five children on vitamin A deficiency and its Prophylaxis.

- To find the effectiveness of Structured Teaching Programme in terms of gaining knowledge and attitude of mothers regarding Vitamin A deficiency and its prophylaxis for under five children.

- To find association between the pre test level of knowledge and attitude among mothers of under five children with their selected demographic variables.

\section{HYPOTHESIS}

H1: There will be significant difference between the pre and post test level of knowledge regarding vitamin A deficiency and its prophylaxis.

$\mathrm{H} 2$ : There will be significant difference between the pre and post test level of attitude regarding vitamin A deficiency and its prophylaxis.

H3: There will be significant association between pre test knowledge score on vitamin A deficiency and its prophylaxis among mothers of under five children with selected demographic variables.

H4: There will be significant association between pre test attitude score on vitamin A deficiency and its prophylaxis among mothers of under five children with selected demographic variables.

\section{MATERIAL \& METHODS}

A pre experimental research design was adopted for the study. The study was conducted at selected village at Villupuram district. 50 samples were selected by using non probability convenient sampling 
Roslin Mangaiyarkarasi. M. et.al. A study to assess the effectiveness of structured teaching programme on knowledge and attitude regarding vitamin A deficiency and its prophylaxis among mothers of under five children at selected village at Tamilnadu.

technique. The pre and post test level knowledge and attitude was assessed by

using structured knowledge questionnaires and attitude scale respectively.

\section{RESULT AND DISCUSSION}

Table 1: Frequency and Percentage distribution of pre and post test level of knowledge among mothers of under five children on vitamin A deficiency and its Prophylaxis. $\mathrm{N}=50$

\begin{tabular}{|l|l|l|l|l|}
\hline \multirow{2}{*}{ Level of Knowledge } & Pre Test & Post Test \\
\cline { 2 - 6 } & Frequency & Percentage & Frequency & Percentage \\
\hline Inadequate Knowledge & 42 & $84 \%$ & 0 & $0 \%$ \\
\hline Moderate Knowledge & 8 & $16 \%$ & 9 & $18 \%$ \\
\hline Adequate Knowledge & 0 & $0 \%$ & 41 & $82 \%$ \\
\hline
\end{tabular}

Table 1 shows that among 50 samples, in pre test level of knowledge $42(84 \%)$ had inadequate knowledge, $8(16 \%)$ had moderate knowledge and none of them $(0 \%)$ had adequate knowledge and in post test level of knowledge among 50 samples none of them $(0 \%)$ had inadequate knowledge, $9(18 \%)$ had moderate knowledge and $41(82 \%)$ had adequate knowledge.

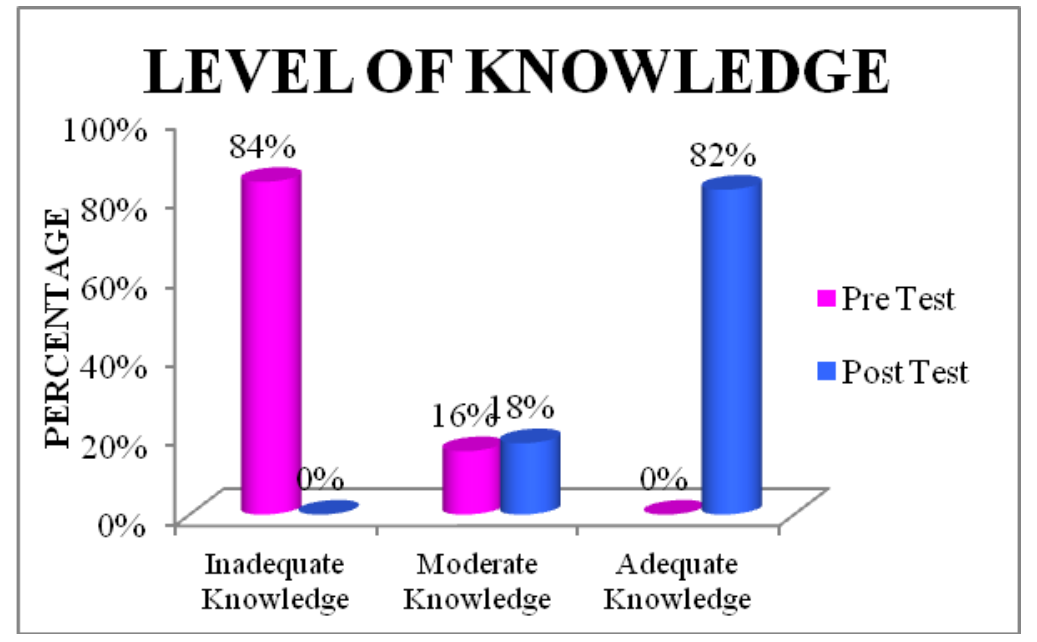

Table 2: Frequency and Percentage distribution of pre and post test level of attitude among mothers of under five children on vitamin A deficiency and its Prophylaxis. $\mathrm{N}=\mathbf{5 0}$

\begin{tabular}{|l|l|l|l|l|}
\hline \multirow{2}{*}{ Level of Attitude } & Pre test & Post test \\
\cline { 2 - 5 } & Frequency & Percentage & Frequency & Percentage \\
\hline Negative Attitude & 40 & $80 \%$ & 0 & $0 \%$ \\
\hline Neutral Attitude & 10 & $20 \%$ & 8 & $16 \%$ \\
\hline Positive Attitude & 0 & $0 \%$ & 42 & $84 \%$ \\
\hline
\end{tabular}

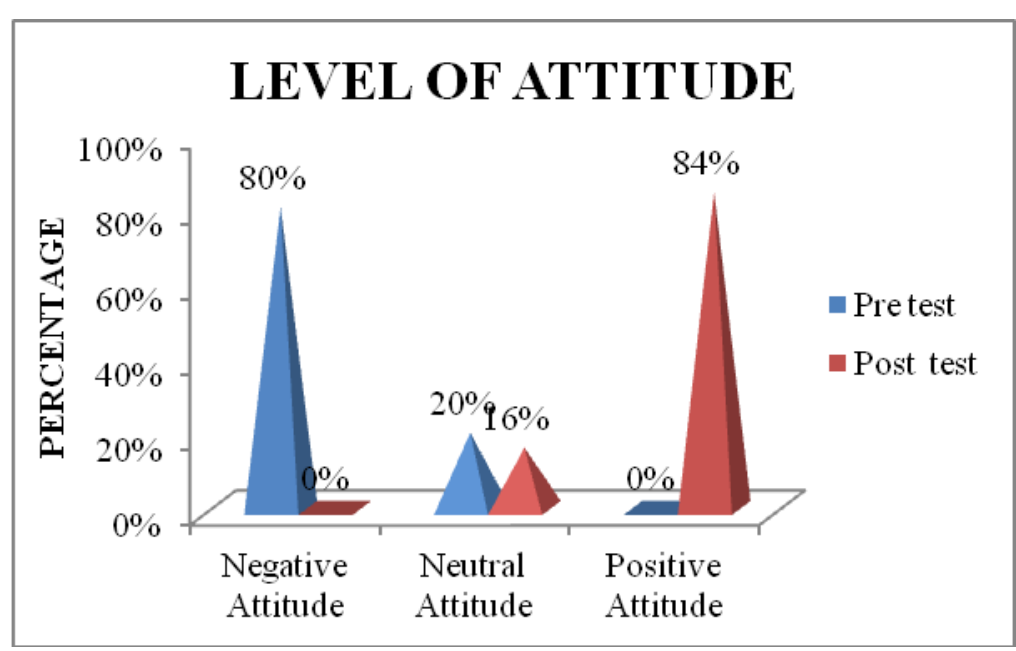


Roslin Mangaiyarkarasi. M. et.al. A study to assess the effectiveness of structured teaching programme on knowledge and attitude regarding vitamin a deficiency and its prophylaxis among mothers of under five children at selected village at Tamilnadu.

Table 2 shows that in pre test level of attitude among 50 samples40 (80\%) had negative attitude, $10(20 \%)$ had Neutral attitude and none of them $(0 \%)$ had positive

attitude and in post test level of attitude among 50 samples none of them $(0 \%)$ had negative attitude, $8(16 \%)$ had neutral attitude and $42(84 \%)$ had positive attitude.

Table 3: Effectiveness of structured teaching programme on knowledge and attitude regarding vitamin A deficiency and its prophylaxis among mothers of under five children. $\mathrm{N}=50$

\begin{tabular}{|l|l|l|l|l|l|l|l|}
\hline & Pre test & Post test & \multirow{2}{*}{ Mean difference } & \multirow{2}{*}{ Standard error } & \multirow{2}{*}{ T value } \\
\cline { 2 - 5 } & Mean & Standard deviation & Mean & Standard deviation & & & \\
\hline Knowledge & 7.76 & 2.17 & 16.68 & 1.81 & 8.92 & 0.281 & $31.74 * \mathrm{HS}$ \\
\hline Attitude & 8.98 & 3.47 & 24.56 & 3,45 & 15.58 & 0.43 & $36.23 * \mathrm{HS}$ \\
\hline
\end{tabular}

\begin{tabular}{|c|c|c|c|c|c|c|}
\hline S. No & Demographic Variables & $\begin{array}{l}\text { Inadequate } \\
\text { Knowledge }\end{array}$ & $\begin{array}{l}\text { Moderate } \\
\text { Knowledge } \\
\end{array}$ & $\begin{array}{l}\text { Adequate } \\
\text { Knowledge } \\
\end{array}$ & Chi Square & P value \\
\hline \multirow[t]{6}{*}{1} & \multicolumn{4}{|l|}{ Age of mother } & \multirow[t]{6}{*}{8.277} & \multirow{6}{*}{$\begin{array}{l}0.406 \\
\mathrm{NS}\end{array}$} \\
\hline & a. $18-20$ years & 0 & 0 & 0 & & \\
\hline & b.21-23years & 12 & 2 & 0 & & \\
\hline & c. $24-26$ years & 13 & 1 & 0 & & \\
\hline & d.27-29 years & 15 & 2 & 0 & & \\
\hline & e. 30 and above & 2 & 3 & 0 & & \\
\hline \multirow[t]{6}{*}{2} & \multicolumn{4}{|l|}{ Educational qualification } & \multirow[t]{6}{*}{14.36} & \multirow{6}{*}{$\begin{array}{l}0.72 \\
\text { NS }\end{array}$} \\
\hline & a. No formal education & 0 & 0 & 0 & & \\
\hline & b. Primary school & 3 & 0 & 0 & & \\
\hline & c. High school & 22 & 1 & 0 & & \\
\hline & d. Higher secondary & 15 & 3 & 0 & & \\
\hline & e. Graduate & 2 & 4 & 0 & & \\
\hline \multirow[t]{6}{*}{3} & \multicolumn{4}{|l|}{ Occupation } & \multirow[t]{6}{*}{5.357} & \multirow{6}{*}{$\begin{array}{l}0.718 \\
\text { NS }\end{array}$} \\
\hline & a. Daily wages & 0 & 0 & 0 & & \\
\hline & b. Govt. employee & 0 & 0 & 0 & & \\
\hline & c. Private employee & 6 & 4 & 0 & & \\
\hline & d. Business & 0 & 0 & 0 & & \\
\hline & e. Housewife & 36 & 4 & 0 & & \\
\hline \multirow[t]{6}{*}{4} & \multicolumn{4}{|l|}{ Family monthly income } & \multirow[t]{6}{*}{9.325} & \multirow{6}{*}{$\begin{array}{l}0.315 \\
\text { NS }\end{array}$} \\
\hline & a. $<5000$ & 0 & 0 & 0 & & \\
\hline & b.5001-10000 & 3 & 0 & 0 & & \\
\hline & c. $10001-15000$ & 15 & 0 & 0 & & \\
\hline & d.15001-20000 & 17 & 3 & 0 & & \\
\hline & e. $>20000$ & 7 & 5 & 0 & & \\
\hline \multirow[t]{5}{*}{5} & \multicolumn{4}{|l|}{ Religion } & \multirow[t]{5}{*}{0.828} & \multirow{5}{*}{$\begin{array}{l}0.991 \\
\text { NS }\end{array}$} \\
\hline & a. Hindu & 38 & 8 & 0 & & \\
\hline & b. Christian & 4 & 0 & 0 & & \\
\hline & c. Muslim & 0 & 0 & 0 & & \\
\hline & d. others & 0 & 0 & 0 & & \\
\hline \multirow[t]{4}{*}{6} & Type of family & & & & 4.44 & 0.349 \\
\hline & a. Nuclear family & 22 & 1 & 0 & & NS \\
\hline & b. Joint family & 18 & 6 & 0 & & \\
\hline & c. Extended family & 2 & 1 & 0 & & \\
\hline 7 & Dietary habits & & & & 0.396 & 0.82 \\
\hline & a. Vegetarian & 2 & 0 & 0 & & NS \\
\hline & b. Non Vegetarian & 40 & 8 & 0 & & \\
\hline 8 & No. of children & & & & 0.951 & 0.917 \\
\hline & a. One & 33 & 5 & 0 & & NS \\
\hline & b. Two & 9 & 3 & 0 & & \\
\hline & c. Three or more. & 0 & 0 & 0 & & \\
\hline 9 & Previous knowledge regar & ng vitamin $\mathrm{A}$ & & & 20.96 & $0.00002 *$ \\
\hline & a. Yes & 3 & 6 & 0 & & $\mathrm{~S}$ \\
\hline & b. No & 39 & 2 & 0 & & \\
\hline 10 & Source of information & & & & 25.21 & $0.0003^{*}$ \\
\hline & a. Media & 0 & 1 & 0 & & \\
\hline & b. Health Worker & 2 & 5 & 0 & & \\
\hline & c. Relatives & 1 & 0 & 0 & & \\
\hline & d. Never Heard & 39 & 2 & 0 & & \\
\hline
\end{tabular}

Table 3 reveals that in Knowledge pre test mean was 7.76 with the standard deviation of 2.17 and the post test mean was
16.68 with the standard deviation of 1.81 . The mean difference of pre and post test is 8.92; standard error is 0.281 . The ' $\mathrm{T}$ ' value 
Roslin Mangaiyarkarasi. M. et.al. A study to assess the effectiveness of structured teaching programme on knowledge and attitude regarding vitamin A deficiency and its prophylaxis among mothers of under five children at selected village at Tamilnadu.

is 31.74 is Highly Significant at $p<0.05$ in Attitude the pre test mean was 8.98 with the standard deviation of 3.47 and the post test mean was 24.56 with the standard deviation of 3.45. The mean difference of pre and post test is 15.58; standard error is 0.43 . The ' $\mathrm{T}$ ' value is 36.23 is Highly Significant at $\mathrm{p}<0.05$. Hence the finding indicates that the knowledge and attitude level of mother of under five children are improved after structured teaching programme.
Table 4 shows that there is significant association between level of knowledge with previous knowledge regarding vitamin $\mathrm{A}$ and source of information at $\mathrm{p}<0.05$ and there is no significant association between the level of knowledge with age of mother, Educational qualification, occupation, Family monthly income, Religion, type of family, Dietary habits and No .of children.

Table 5: Association between pre test level of attitude with their selected socio demographic variables.

\begin{tabular}{|c|c|c|c|c|c|c|}
\hline S. No & Demographic Variables & Negative & Neutral & Positive & Chi Square & P value \\
\hline \multirow[t]{6}{*}{1} & \multicolumn{4}{|l|}{ Age of mother } & \multirow{6}{*}{13.04} & \multirow{6}{*}{$\begin{array}{l}0.110 \\
\text { NS }\end{array}$} \\
\hline & a. $18-20$ years & 0 & 0 & 0 & & \\
\hline & b.21-23years & 12 & 2 & 0 & & \\
\hline & c. $24-26$ years & 13 & 1 & 0 & & \\
\hline & d.27-29 years & 14 & 3 & 0 & & \\
\hline & e.30 and above & 1 & 4 & 0 & & \\
\hline \multirow[t]{6}{*}{2} & \multicolumn{4}{|l|}{ Educational qualification } & \multirow{6}{*}{10.8} & \multirow{6}{*}{$\begin{array}{l}0.213 \\
\text { NS }\end{array}$} \\
\hline & a. No formal education & 0 & 0 & 0 & & \\
\hline & b. Primary school & 3 & 0 & 0 & & \\
\hline & c. High school & 21 & 2 & 0 & & \\
\hline & d. Higher secondary & 14 & 4 & 0 & & \\
\hline & e. Graduate & 2 & 4 & 0 & & \\
\hline \multirow[t]{6}{*}{3} & \multicolumn{4}{|l|}{ Occupation } & \multirow{6}{*}{3.125} & \multirow{6}{*}{$\begin{array}{l}0.926 \\
\text { NS }\end{array}$} \\
\hline & a. Daily wages & 0 & 0 & 0 & & \\
\hline & b. Govt. employee & 0 & 0 & 0 & & \\
\hline & c. Private employee & 6 & 4 & 0 & & \\
\hline & d. Business & 0 & 0 & 0 & & \\
\hline & e. Housewife & 34 & 6 & 0 & & \\
\hline \multirow[t]{6}{*}{4} & \multicolumn{4}{|l|}{ Family monthly income } & \multirow{6}{*}{5} & \multirow{6}{*}{$\begin{array}{l}0.757 \\
\text { NS }\end{array}$} \\
\hline & a. $<5000$ & 0 & 0 & 0 & & \\
\hline & b.5001-10000 & 3 & 0 & 0 & & \\
\hline & c. $10001-15000$ & 13 & 2 & 0 & & \\
\hline & d.15001-20000 & 17 & 3 & 0 & & \\
\hline & e. $>20000$ & 7 & 5 & 0 & & \\
\hline \multirow[t]{5}{*}{5} & \multicolumn{4}{|l|}{ Religion } & \multirow{5}{*}{1.087} & \multirow{5}{*}{$\begin{array}{l}0.982 \\
\text { NS }\end{array}$} \\
\hline & a. Hindu & 36 & 10 & 0 & & \\
\hline & b. Christian & 4 & 0 & 0 & & \\
\hline & c. Muslim & 0 & 0 & 0 & & \\
\hline & d. others & 0 & 0 & 0 & & \\
\hline \multirow[t]{4}{*}{6} & Type of family & & & & & \\
\hline & a. Nuclear family & 21 & 2 & 0 & 343 & 0.488 \\
\hline & b. Joint family & 17 & 7 & 0 & 3.43 & NS \\
\hline & c. Extended family & 2 & 1 & 0 & & \\
\hline 7 & Dietary habits & & & & & \\
\hline & a. Vegetarian & 1 & 1 & 0 & 1.171 & $\begin{array}{l}0.556 \\
\text { NS }\end{array}$ \\
\hline & b. Non Vegetarian & 39 & 9 & 0 & & \\
\hline 8 & No. of children & & & & & \\
\hline & a. One & 32 & 6 & 0 & & 0.882 \\
\hline & b. Two & 8 & 4 & 0 & 1.754 & NS \\
\hline & c. Three or more. & 0 & 0 & 0 & & \\
\hline 9 & Previous knowledge regar & ng vitamin & & & & \\
\hline & a. Yes & 1 & 8 & 0 & 32.55 & $0.00001 \%$ \\
\hline & b. No & 39 & 2 & 0 & & \\
\hline 10 & Source of information & & & & & \\
\hline & a. Media & 0 & 1 & 0 & & \\
\hline & b. Health Worker & 1 & 6 & 0 & 32.75 & $\begin{array}{l}0.00001^{*} \\
S\end{array}$ \\
\hline & c. Relatives & 0 & 1 & 0 & & \\
\hline & d. Never Heard & 39 & 2 & 0 & & \\
\hline
\end{tabular}


Roslin Mangaiyarkarasi. M. et.al. A study to assess the effectiveness of structured teaching programme on knowledge and attitude regarding vitamin A deficiency and its prophylaxis among mothers of under five children at selected village at Tamilnadu.

$<0.05$ and there is no significant association between the level of attitude with age of mother, Educational qualification, occupation, Family monthly income, Religion, type of family, Dietary habits and No .of children.

\section{DISCUSSION}

The first objective of the study is to assess the knowledge and attitude among mothers of under five children on vitamin A deficiency and its Prophylaxis.

The finding shows that in pre test level of knowledge majority of majority of mothers $42 \quad(84 \%)$ had inadequate knowledge and 8 (16\%) had moderate knowledge. In post test level of knowledge majority of mothers41 (82\%) had adequate knowledge, 9 (18\%) had moderate knowledge.

In level of attitude that in pre test majority of mothers $40(80 \%)$ had negative attitude, 10 (20\%) had Neutral attitude. In post test majority of mothers $42(84 \%)$ had positive attitude, $8(16 \%)$ had neutral attitude.

The second objective of the study is to find the effectiveness of Structured Teaching Programme in terms of gaining knowledge and attitude of mothers regarding Vitamin A deficiency and its prophylaxis for under five children.

The finding of the study shows that In Knowledge pre test mean was 7.76 with the standard deviation of 2.17 and the post test mean was 16.68 with the standard deviation of 1.81 . The mean difference of pre and post test is 8.92; standard error is 0.281 . The ' $\mathrm{T}$ ' value is 31.74 is Highly Significant at $\mathrm{p}<0.05$ it indicates that the knowledge level of mother of under five children are improved after structured teaching programme. Hence hypothesis H1 is accepted.

In Attitude the pre test mean was 8.98 with the standard deviation of 3.47 and the post test mean was 24.56 with the standard deviation of 3.45 . The mean difference of pre and post test is 15.58; standard error is 0.43 . The ' $\mathrm{T}$ ' value is
36.23 is Highly Significant $p<0.05$ it indicates that the knowledge level of mother of under five children are improved after structured teaching programme. Hence hypothesis $\mathrm{H} 2$ is accepted.

The third objective of the study is to association between the pre test level of knowledge and attitude among mothers of under five children with their selected demographic variables.

The finding of the study shows that there is significant association between level of knowledge with previous knowledge regarding vitamin $\mathrm{A}$ and source of information at $\mathrm{p}<0.05$. Hence the $\mathrm{H} 3$ is accepted.

The finding of the study shows that there is significant association between level of attitude with previous knowledge regarding vitamin $\mathrm{A}$ and source of information at $\mathrm{p}<0.05$. Hence the $\mathrm{H} 4$ is accepted.

\section{CONCLUSION}

The study finding reveals that in level of knowledge pre test mean was 7.76 with the standard deviation of 2.17 and the post test mean was 16.68 with the standard deviation of 1.81. The knowledge ' $\mathrm{T}$ ' value is 31.74 is Highly Significant at $p<0.05$. In level of attitude the pre test mean was 8.98 with the standard deviation of 3.47 and the post test mean was 24.56 with the standard deviation of 3.45. The attitude ' $\mathrm{T}$ ' value is 36.23 is Highly Significant $p<0.05$. Hence the study concluded that structured teaching programme was effective and improved knowledge and attitude regarding vitamin $\mathrm{A}$ deficiency and its prevention among mothers of under five children.

Acknowledgement: None

Conflict of Interest: None

Source of Funding: None

Ethical Approval: Approved 
Roslin Mangaiyarkarasi. M. et.al. A study to assess the effectiveness of structured teaching programme on knowledge and attitude regarding vitamin A deficiency and its prophylaxis among mothers of under five children at selected village at Tamilnadu.

\section{REFERENCES \\ BOOK REFERENCE:}

1. Carol Jean West Suitor and Merrily Forbes Crowley, (1984), Nutrients in Health, Nutrition principles and application in Health promotion, 2nd edition, Philadelphia, J.B.Lippincott Company, 42-43.

2. Dandekar and Sucheta. P., (2002) vitamins, Medical Biochemistry, 2nd Edition, New Delhi, B.I. Churchill Living Stone (p) Ltd., 393-38.

3. Helen M.Baskar and Rachel Lees, (1996), Vitamins, Nutrition and Dietetics for Healthcare 9th Edition, New York, Churchill Living Stone 35-38.

4. Kamalam. S ,(2005), “ Essentials in Community Health Nursing Practice", $1^{\text {st }}$ edition, New Delhi, Jaypee Publications, Pg no.235-257.

5. Park. K, (2008) "Essential of Community Health Nursing", $\quad 5^{\text {th }}$ edition, M/S Banarsidas Publications, Pg no. 234-245.

6. Polit,D.F.,\&Hungler,B.P (2006), "Nursing research principles and method", 9th edition, USA, Lippincott publications, PP No: 320-350.

7. Rotharic C.R. (2004), "Research Methodology", $1^{\text {st }}$ edition, New Dehli, Age International Publications, Pg no.60-62.

8. Sheila L. Videback (2002), "Nursing theory- Utilization and Application, Second edition, Philadelphia, Mosby Publications. Pg no 219- 237.

9. Viswanadhan J., Desai. B. Avalokhitha, (1989), vitamins, Minerals and Their Deficiency States, Achar's Text Book of Pediatrics, 3rd Edition, Madras Orient Long Man, 5-86.

10. WHO (1990), Guidelines for training Community Health workers in nutrition, $2^{\text {nd }}$ edition, New Delhi, Jaypee Publications,. Pg no. 245- 389.

11. Wong. L.Donna, Hocken Berry J.Marilyn, et al., (2003), Health Problems During Infancy, 7th Edition, China, Mosby Company, 554-556.

\section{JOURNAL REFERENCE:}

1. Ankit M Sheth, Matib M Rangoonwala, Kaushik K Lodhiya, Dipesh D Zalavadiya, Nirav B Joshi A Study on Awareness and Practice Regarding Vitamin A Intake and Its Deficiency Disorders Among Mothers Of Pre-School Children In Khirasara Village, Rajkot, Gujarat, Ntl J Community Med 2016; 7(6):505-509.
2. Anshupik Singh Kushwaha, Dr. Karesh Prasad Effectiveness of Information Booklet on knowledge regarding Vitamin A deficiency and its prophylaxis among mothers of under five year children in selected slum area Bhopal, International Journal of Health and Biological Sciences2018; Vol. 1, No. 1:9-15.

3. Bhatia Anmol A Descriptive Study to assess The Knowledge Regarding Vitamin A Deficiency Disorders among Mothers of Under Five Children in Selected Rural Area of District Ludhiana, Punjab, Int. J. Nur. Edu. and Research 2017; vol 5 No 4: 395398.

4. Firdous Ahmad Shah, Tabashir Bashir, A Study to Assess the Effectiveness of Structured Teaching Program on Knowledge Among Mothers of Under-Five Children regarding Prevention of Vitamin A Deficiency in Govt. Primary Health Center Kakapora, Pulwama Kashmir, Indian journal of research; 2019; vol 8 No 1.

5. Jitendra Khatri, Effectiveness of Structured Teaching Program on Vitamin- A deficiency among the mother's of under-five children, IOSR Journal of Nursing and Health Science (IOSR-JNHS) ， 2014; Volume 3, Issue $2: 54-57$

6. Kaur S. Prevalence Of Vitamin A And Vitamin D Deficiency Amongst Children Under Five Years And Women Of Reproductive Age In Madhya Pradesh. Indian J Community Health; 2015;27 (Supp 1).

7. Kuldeep Singh, Effectiveness of STP on Knowledge Regarding Prevention of Vitamin A Deficiency in Children among Mothers of Children below Five Years, journal of nursing science and practice 2016; Vol 6, No 2

8. Kumari Richa, Gupta Alka, Prasad Ranu, Tripathi Jaya. Prevalence of Vitamin A deficiency among school going children of Jasra block of Allahabad, India. Journal of Applied and Natural Science. 2018; 10(1):45.

9. Laxmaiah A, Nair MK, Arlappa N, Raghu P, Balakrishna N, Rao KM, et al. Prevalence of ocular signs and subclinical Vitamin A deficiency and its determinants among rural preschool children in India. Public Health Nutr 2012;15:568-77.

10. Muliyil DE, Rose A, Senthamizh SV, Chatterjee T, Helan J, Kang G, Muliyil J, 
Roslin Mangaiyarkarasi. M. et.al. A study to assess the effectiveness of structured teaching programme on knowledge and attitude regarding vitamin A deficiency and its prophylaxis among mothers of under five children at selected village at Tamilnadu.

Prevalence and risk factors of Vitamin A deficiency in children and women of childbearing age in a Southern Indian Tribal Population: A cross-sectional study.Indian J Community Med 2019; vol 44, issue 2:162165.

11. Nimmathota Arlappa, Nagalla Balakrishna, Avula Laxmaiah, GNV Brahmam Vitamin A Deficiency Disorders among the Rural Pre-School Children of South India, International Journal of Nutrition 2016; vol 2 issue 1: 1-11

12. Sachdeva S, Alam S, Beig FK, Khan Z, Khalique N. Determinants of vitamin A deficiency amongst children in Aligarh District, Uttar Pradesh. Indian Pediatr. 2011; 48(17):853-4.

13. Shanthi S, Effectiveness of Visual Package on Knowledge regarding Vitamin ' $A$ ' deficiency and its Prevention among mothers of under five Children in a Selected Community at Mangalore, Int. J. Adv. Nur. Management; 2017; vol 5 No 3: 237-240.

14. Sonu Varghese, Soumya Manuel, Tessy A, Vineetha CR, Sheeja S, A Study to Assess the Knowledge on Mothers of Underfive
Children Regarding Importance of Vitamin A among Selected Areas of Pallithottam, Kollam, Asian J. Nursing Education and Research; 2020; vol 10 No 1:84-88

15. Srivastava KP, Abedi AJ, Mehnaz S, Ansari MA, Srivastava JP,. Intake of vitamin A \& its association with nutrition status of preschool children. Int $\mathrm{J}$ Community Med Public Health 2015; 2:489-93.

16. Thunga Usha Rani M.Sc.(Psy) "A Study to Assess the Knowledge and Practices on Vitamin A Deficiency among School Children in Naziabad (District), Telangana, India." IOSR Journal of Nursing and Health Science (IOSR-JNHS), 2018; vol. 7,

How to cite this article: Roslin Mangaiyarkarasi. M., Kumudhavalli. D, R. Karthi. A study to assess the effectiveness of structured teaching programme on knowledge and attitude regarding vitamin A deficiency and its prophylaxis among mothers of under five children at selected village at Tamilnadu. International Journal of Research and Review. 2021; 8(9): 234-241. DOI: https://doi.org/10.52403/ijrr.20210932 